Article

\title{
Ritual Treatment of Fortunate and Unfortunate Dead by the Chinese Redemptive Society Déjiāo in Thailand
}

\section{Bernard Formoso}

Department of Ethnology, Paul Valéry University-Montpellier 3, Route de Mende, 34199 Montpellier, France; bernard.formoso@univ-montp3.fr

Received: 22 April 2020; Accepted: 11 May 2020; Published: 15 May 2020

check for updates

\begin{abstract}
This paper compares the ritual management of fortunate and unfortunate dead (hungry ghosts) by a Chinese new religious movement named Déjiāo 德教 (lit. Teaching of Virtue), which emerged in Chaozhou (the northeast of Guangdong province) in 1939, before spreading to Southeast Asia after World War II. Based on ethnographic data collected in Chaozhou and Thailand between 1993 and 2005, the analysis reveals significant differences concerning both the ideological and performative aspects of the ritual processing of the two categories of dead. The funeral care of orphaned dead by Déjiāo conforms to the Chaozhou tradition of $x i \bar{u}$ gūgú 修孤骨, a festival of second burial allegedly devised during the Song dynasty by a local Buddhist monk; most of his sequences require the activity of mediums. Turned toward the salvation of the unfortunate dead, this festival was enriched by a universalist ambition through its adaptation to the Thai context. In doing so, it perfectly expresses the moral and religious goals of Déjiāo, one of the most active Chinese redemptive societies.
\end{abstract}

Keywords: Chinese funerary rites; Déjiāo 德教; redemptive society; hungry ghosts; xīu gūgú 修孤骨

\section{Introduction}

As pointed out by Watson (1988b, p. 9), the Han Chinese belief system makes the fate of the living depend directly upon the ritual and geomantic treatment of the dead. In this cultural context, the well-being of the deceased and their descendants are conceived to be dialectically related. Hence, the need for agnates to properly perform the rites that build up and maintain the relationship with members of the kin group who passed away. Among these rites, the funeral is of crucial importance by settling the volatile spirit of the dead in the afterworld. It consists of many sequences that necessarily implies the use of professionals.

Thailand is the country of Southeast Asia of which the citizens of Chinese ancestry are the largest in number ${ }^{1}$ and among the best socially integrated, to the point of controlling, at the turn of the twenty-first century, both the domestic economy and the local political sphere. However, from 1932 to the late 1950s, Thai nationalist rulers imposed on immigrants a strong assimilationist policy, which resulted in a loss of Chinese language and culture among their descendants. As a consequence, officiants able to conduct death rituals are locally few in number and for most of them perform in charitable associations, known as shàntáng ("halls for good deeds", 善堂). These organizations, which developed in China during the nineteenth century (Rowe 1984, p. 248; Naquin 2000, pp. 653-69), and blossomed

1 Their number was estimated to be 9.2 million in 2019, including Thai-Chinese. They represent about $13.5 \%$ of the kingdom's population. 
in Southeast Asia from the turn of the twentieth century onwards, offer services of various kinds in Thailand. They provide material assistance to the poor and emergency relief for victims of fire, flood and other disasters. Their rescue teams equipped with ambulances intervene in traffic accidents to administer first aid to the injured while moving them to the hospital, or to transport the dead to the mortuary. The richest of them manage hospitals of their own, and apply not only first aid, but also health care to casualties. Their charitable activities being closely linked to the combined worship of Buddhist saints and Immortals of the Daoist pantheon, the shàntáng are also the main source of specifically Chinese religious activity in the Thai context. They train new generations of priests and serve as rallying points for great annual celebrations. They also manage cemeteries and provide the necessary know-how to arrange funerals true to the traditional pattern.

In previous publications I have shown that the benevolent halls operating in Thailand derive from five chains of temples traceable to Chaozhou, in the northeast of Guangdong province. They ramify in the main cities, and the most dynamic of these chains of temples, named Déjiāo, relies on a network of more than 90 branches distributed in all the different Thai provinces (Formoso 1996, 2010). Déjiāo, while assuming the various functions of the shàntáng, is more fundamentally a new religious movement (NRM), whose characteristics inscribe it into the constellation of the Chinese "redemptive societies", that flourished in China during the republican era (1911-1949) (Duara 2001; Palmer 2011, p. 22). The roots of this self-proclaimed "moral uplifting" organization date back to 1939, when Chaozhou mediums using the spirit-writing technique of fúji (扶乩) started to receive enactments and instructions from four Daoist “honorable masters" (shīzūn 蒒尊) ${ }^{2}$ and from Jīgōng Huófó 济公活佛, the Buddhist "crazy" monk who lived in the Southern Song. ${ }^{3}$ Facing the chaotic situation of the Sino-Japanese war and reacting to the emergence of secular materialism in China, the founders of Déjiāo intended to promote a new doctrine made of Confucian ethics together with Buddhist compassion and Daoist beliefs, while adding to its shīzūn Jesus Christ and the Prophet Muhammad. This synthesis is succinctly exposed in the Déjiāo xīndĭan 德教心典; a liturgical text of only 346 characters revealed through spirit-writing in 1942. After World War II, Déjiāo spread to Singapore, Malaysia, and Thailand, shortly before being outlawed in the Peoples' Republic of China (PRC). It has currently over 250 congregations in Southeast Asia, and in the mid-1990s it raised funds to reintroduce the movement in the PRC, although the movement, immediately assimilated to another NRM, Fălún Gōng 法轮功, was banned by the Chinese authorities, because of its supposed millennial character. Despite this ban, Déjiāo took advantage of the luxuriant and open-ended character of Chinese religiosity, as well as the local demand for financial support, by negotiating with local Buddhist and Daoist temples the extension of their worship to its most typical deities. This Trojan horse strategy was often combined with the miraculous appointment of top members of these institutions as chairs of the new congregations. Although the local Religious Affairs Bureaus sometimes heard about such infiltrations, they did not interfere as long as the adepts did not display overt signs of religious identity and avoided proselytizing openly. This tolerant attitude suggests that, in the view of the authorities, Déjiāo was not considered a real threat. The fact is, the spread of the movement remained limited in the PRC to a few hundred natives of Chaozhou and about twenty congregations.

The leading function that the adepts confer to "divine instructions" delivered through spirit-writing induces a worship variability, which in turn largely contributes to the outstanding adaptability of this movement to political contingencies. For example, Déjiāo in Thailand responded to the state assimilationist injunctions of the Chinese immigrants by extending its charitable activities to the whole population of the kingdom. On the contrary, in Malaysia, the communitarian policy conduced in the wake of British colonization led it to exclusively serve the interests of the Chinese community. However, the other side of the coin is a noticeable lack of social cohesiveness and cultural homogeneity.

2 These masters are Liu Chunfang (柳春芳), Yang Junsong (楊筜松), Wu Mengwu (呉夢吾), and Zhang Xuantong (張玄同). For a very detailed study of the legendary life of this monk, see Shahar (1998). 
Less than other Chinese NRMs, Déjiāo can be convincingly interpreted through an organic view of community, neither a reifying nor a monolithic interpretation of tradition. Considered as a whole, it is a loosely but structured chain of local spirit-writing groups, which mainly share moral and charitable goals, around a basic doctrine turned toward the salvation of mankind as a whole.

The mortuary rituals supervised by priests of Déjiāo reflect this religious plasticity to varying degrees. While the officiants who perform funerals at the request of families rely on the postulated efficiency of a standard liturgy, they combine this orthopraxy with contingent and prospective acts induced by spirit-writing when they are in charge of the transfer of orphaned souls to the netherworld. In the following pages, I compare funerals and the ritual management of restless ghosts by taking into account the onto-cosmological objective they pursue, as well as their ideological and performative aspects. In line with the focus that Paul Katz rightly puts on processes of ritual standardization escaping the state's control (Katz 2007, pp. 73-74), I show that the funerary treatment of the unfortunate dead by Déjiāo adepts originating from Chaozhou has stabilized in a local form called $x i \bar{u} g \bar{u} q u$, which takes up, in an original fashion, the tradition of second burial, which is widespread in Southeast China. ${ }^{4}$ The fieldwork on which this article is based was carried out in Thailand and in Chaozhou from 1993 to 2005, through several missions.

\section{Fortunate Versus Unfortunate Dead}

In the Han Chinese belief system, also endorsed and performed by Déjiāo, the normal or fortunate dead are those who die of a natural death, at a respectable age. Their transfer and existence in the underworld are taken care of by their descendants through funerals properly performed and further devotions in the form of regular offerings. If, in pre-Communist China, a male descent was considered essential, because it fell to him to supervise both the funeral and the ancestor worship, this obligation is no longer strictly respected overseas. As noted by some observers (Eliott 1955; Willmott 1970), the urban nature of the Southeast Asian Chinese communities, the dispersion of lineage members in search of business opportunities, and the proliferation of intermarriages with native women, are all factors unfavorable to the persistence of strong corporate groups centered on the worship of common ancestors. In this context, the kinship system tends to be bilateral and a growing number of daughters and more distant relatives compensate for the lack of male descendants, by endorsing the cost of the funeral and making regular offerings at the tomb.

Despite this widening of ritual roles to women, the main purpose of funerals remains unchanged. It is always a question of maintaining ties of solidarity and the circulation of flows of life and prosperity between the past and present generations of the agnate group. Mortuary rites are from this point of view at the heart of crucial symbolic issues for kinship: displaying cohesion and securing both progeny, health, long life and wealth, thanks to the benevolent intervention of the ancestors. The regular transfer of food, mock money and paper models of goods to the deceased serves this purpose by submitting them to the gift economy.

In contrast, the unfortunate dead are orphaned souls who died prematurely, by accidents, homicide, or suicide, and who are therefore excluded from ancestor commemoration. Their life cycle was abruptly interrupted and their soul can no longer return to it. The category is also fueled by victims of disasters or conflicts whose identity remains unknown, and by marginalized individuals without descendants or having broken all family ties forever. In both cases, "they can neither pass on to the world of the dead nor be reabsorbed into the family matrix. They must remain in a place where their unexpected vitality condemns them to a miserable life, as exiles in the world of the living" (Schipper 1993, p. 37). The feelings that they arouse among the Chinese are ambivalent. They usually generate a mixture

4 James Watson observes that, in China, the double burial complex is limited to the southern Han peoples (Cantonese, Hakka, Hokkien, Teochew). According to Watson (1993, pp. 90-91), the custom is historically linked to close interactions of these peoples with highlanders of Southeast Asia, where burial and reburial is a common practice. 
of fear and compassion. They are a source of danger because their souls are believed to transform into restless and hungry ghosts, the gūhún 孤魂. Failing to have been transferred to the underworld by means of proper funeral rites, they haunt the world of the living and threaten its safety. Weller (1985, pp. 48-49) observed that an analogy is consciously established in China between ghosts and bandits, to the extent that both of them spontaneously evade any form of control. "Both exist outside the constraints of family, kinship and community," wrote Watson (1988b, p. 9). However, on the other hand, recognizes Weller, the orphaned dead are also assimilated to pitiful beggars who inspire compassion.

The Universal Salvation Festival (pŭdù 普度), that is traditionally performed by local communities in China and overseas during the seventh lunar month, expresses this compassion by inviting, once a year, all the wandering ghosts to come and feast on food offerings in the courtyard of the organizing temples. However, the Chaozhou shàntáng add to this event another, a non-calendar festival, the radical aim of which is to cleanse the social landscape of all its hungry ghosts, by transferring them collectively to the underworld.

According to a local legend, the idea to perform this festival, called xī̄ gūgú, came from Dà Fēng 大峰, a Buddhist monk of the Southern Song dynasty who was later made patron saint of Bàodé Shàntáng 報德善堂 (benevolent hall for the recompense of virtue), the oldest hall for good deeds of the Chaozhou area, established in 1636. Da Feng would have devised the ritual somewhere during the twelfth century, at the time of a plague which ravaged Shantou, the main city of Chaozhou. The saint's objective was twofold: to protect the living by collecting and burying the corpses, and to offer the dead without descendants his followers as an adoptive family, reintegrating them into the cycle of reincarnations by means of the festival and continuous devotion. Shortly after its creation, Déjiāo adopted this festival which concretized around clearly defined goals its ideology of redemption. The salvation of humankind was then thought to find its most obvious and urgent expression in the compassionate care of the orphaned dead. The worshippers' motivations aroused by these moral goals were reinforced by more personal interests: to improve one's karma through the accumulation of good deeds, and to take on the positive and powerful yang property of the bones at the occasion of their reburial, by washing them and completing the process of their physical purification.

The institution of $x i \bar{u} g \bar{u} g \dot{u}$ was introduced in Thailand at the beginning of the twentieth century by the local branch of Bàodé Shàntáng. The association had started its activities in 1897, but the top Chinese leaders who managed it were looking for a royal patronage before opening it officially. King Chulalongkorn (1853-1910) granted his patronage, but under the following conditions: the

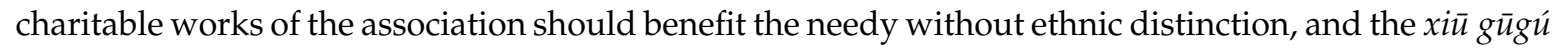
should accommodate Thai custom regarding the malevolent dead. Such customs are linked to the belief that the unfortunate dead are those whose destiny on earth is shortened by bad karma. Before being properly processed through cremation, they must make repentance on earth for at least three years, which correspond to the Buddhist Triple Gem (Buddha, Dharma, Sangha). To this end, the bad dead are buried near the Thai monasteries that are believed to serve as "protective umbrellas" against their malevolent power. The fear that these bad dead arouse among the Thai generally results in their complete abandonment. Their exhumation after three years to organize their cremation is rarely carried out. They become ghosts, endlessly haunting areas of the human world that are carefully avoided by the living.

Urged by the royal requirements, Bàodé Shàntáng modified the xī̄ gūgú liturgy by cremating human remains instead of burying them in a grave, and by leaving Thai families the opportunity to recover their dead for three years. The association performed its first festival in 1910 as part of the official ceremonies marking its official opening. If Chinese coolies made up most of the one hundred bodies processed for the occasion, on the following occurrences, the share of Chinese bodies decreased to the point that from the end of World War II onward most of the bones refined were Thai. The statement applies to both Bàodé Shàntáng, which cremated more than 175,000 bodies between 1910 and 2017, and to other halls for good deeds operating in Thailand. In a national context where the people originating from Chaozhou form about 70 percent of the Chinese community, shàntáng and the 


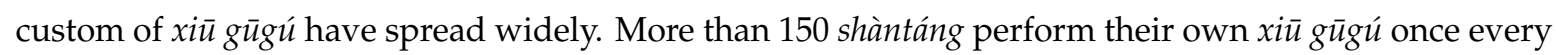
seven to twenty years. Most of them are local branches of Déjiāo.

In contemporary Thailand, the bulk of dead bodies that these charitable associations gather come from prospecting by their volunteers. As I mentioned before, most shàntáng, including those belonging to Déjiāo, have teams of rescuers who assist police and firefighters in case of disasters. Some of them also manage 24-h-emergency squads whose ambulances rescue victims of traffic accidents in close connection with police and hospitals. In return, they appropriate unclaimed bodies and those abandoned by families. Another usual way to collect skeletons on a large scale is to engage in prospecting near Buddhist monasteries, where Thai untimely dead are buried. In return for permission to take away the remains, the shàntáng usually make generous donations to the monasteries.

\section{Funerary Rites Ordered by Families}

Several times a month, the branches of Déjiāo located in large cities of Thailand organize funeral rites at the request of families, an example of which can be seen in Figure 1. The expertise they claim in this domain is all the greater that the services they provide extend to all the towns where Chinese people live, but which have no charitable associations of their own. The Déjiāo associations provide for a fee the officiants, the musicians, the necessary equipment and furniture, mourning garbs, vehicles for the transportation of the body, and even a place in the cemetery they manage. The revenues from this activity represent their main source of income, apart from followers' donations. Their priests, who are able to read texts in Chinese, have learned the liturgy by assisting older and experienced officiants for years. Called xiānshēng 先生 (teacher), they correspond to the "barefoot priests" of the orthodox hierarchy; namely, the lowest category of Daoist officiants. They share with the mediums the same background and, like the former, they combine lay and religious activities.

Déjiāo funerals respect the elementary structure of Chinese death rituals whose most typical features, according to Watson (1988b, pp. 12-15), are the following: (1) public notification of death; (2) donning of mourning clothes; (3) ritualized bathing of the corpse; (4) transfer of food, mock money, and paper models of items to be used in the afterlife from the living to the dead; (5) the preparation and installation of a soul tablet for the dead; (6) the ritualized use of money and the employment of professionals; (7) music to accompany the corpse and to settle the spirit; (8) sealing the corpse in an airtight coffin; (9) expulsion of the coffin from the community.

To these aspects, the wealthiest Chinese families of Thailand add the performance of a gōng déc功德 (acquisition of merit) ritual, seen in Figure 2. Through it, they display their filial piety in several ways. They redeem the wrongdoing of the dead by dramatically overcoming several symbolic trials under the direction of a chief priest, either Buddhist or Daoist. They also offer to the soul vast quantities of gifts and in so doing they proceed to his conversion into a grateful and benevolent ancestor. Traditionally, gonng dé was performed on the forty-ninth day after the burial of the deceased, and it is still the case in Singapore (Tong 2004, p. 47). However, in Thailand, when it is performed, the ritual is usually aggregated to the funeral as its antepenultimate sequence, just before the transfer of the corpse to the cemetery.

Although optional due to its high cost (250,000 Baht on average in 2019, equivalent to US $\$ 8500)$, the gōng dé ritual perfectly expresses one of the main concerns of families organizing a funeral. They wish to give an honorable image of themselves by ostensibly displaying sorrow and filial piety towards the deceased, as well as their unity and prosperity. Given this concern, the families spend, in most cases, huge sums of money ${ }^{5}$ to enact the ritual with as much as luster as possible. They are also eager to attract community leaders to the event, in addition to kin and neighbors. The Déjiāo associations

5 The average sum received by Déjiāo associations for the funeral service, the purchase of a cemetery plot, and the geomantic disposal of the corpse into the grave, gōng de not included, was 650,000 Baht (US \$20,000) in 2019. To these expenses must be added the remuneration of undertakers, donations of money to community associations, as well as the cost of building the grave. We then arrive at amounts approaching the million Baht (US $\$ 30,000)$. 
serve this objective, first by making the mourners profit from their associative networks in order to increase the social impact of the public notification of death, and then by suggesting to the family of the deceased a portfolio of charitable, educative, and cultural associations to whom publicly make donations of money in return for their involvement in the ceremonial presentation of food trays to the dead, which precedes the sealing of the coffin.

Dramatization of the performance is a striking feature of a Chinese and Déjiāo funeral. The mourners wear clothing which indicate their degree of kinship with the dead, and accordingly, their variable obligations regarding the expression of filial piety. Following the instructions of the Déjiāo specialists, they perform in front of the audience a complex series of symbolic acts and pledges of affliction, according to a prescribed scenario that tolerates no improvisation. A clear separation is staged between the mourners and the audience, which takes many forms. In addition to the attire worn by the mourners, they take their meals apart and silently, as a sign of humility and pain. Due to the pollution they absorbed when handling the corpse to wash and dress it, physical contact with them is avoided. A clear spatial demarcation is also established between the place where the ritual takes place and an area facing it where seats are arranged for the comfort of the audience. By all these devices the social boundaries of the family and its identity as a corporate group are ritually set forth.

Death, to the Chinese, is a point of transition from life to afterlife, from the world of the living to the underworld. Accordingly, mortuary rituals are intended to ensure the change of ontological status of the deceased and their passage from one cosmic plane to another in optimal conditions, so that good transgenerational relations can be maintained. The symbolic exchanges that structure funerals are of paramount importance for that purpose. Tong Chee-Kiong perfectly sums up their performative intent when he writes that:

Through the enactment of the rituals, the living descendants give the gift of life to the dead by ensuring their rebirth and transformation into an ancestor. Gift offerings are important because they not only ensure the well-being of the ancestor through the provision of items that they will need in the Otherworld, but the gifts act as an agent of transformation, converting a hungry ghost into a property-owning spirit. [ . . ] In return the descendants receive gifts of luck, wealth, good health, long life and the general well-being of the family. (Tong 2004, p. 7)

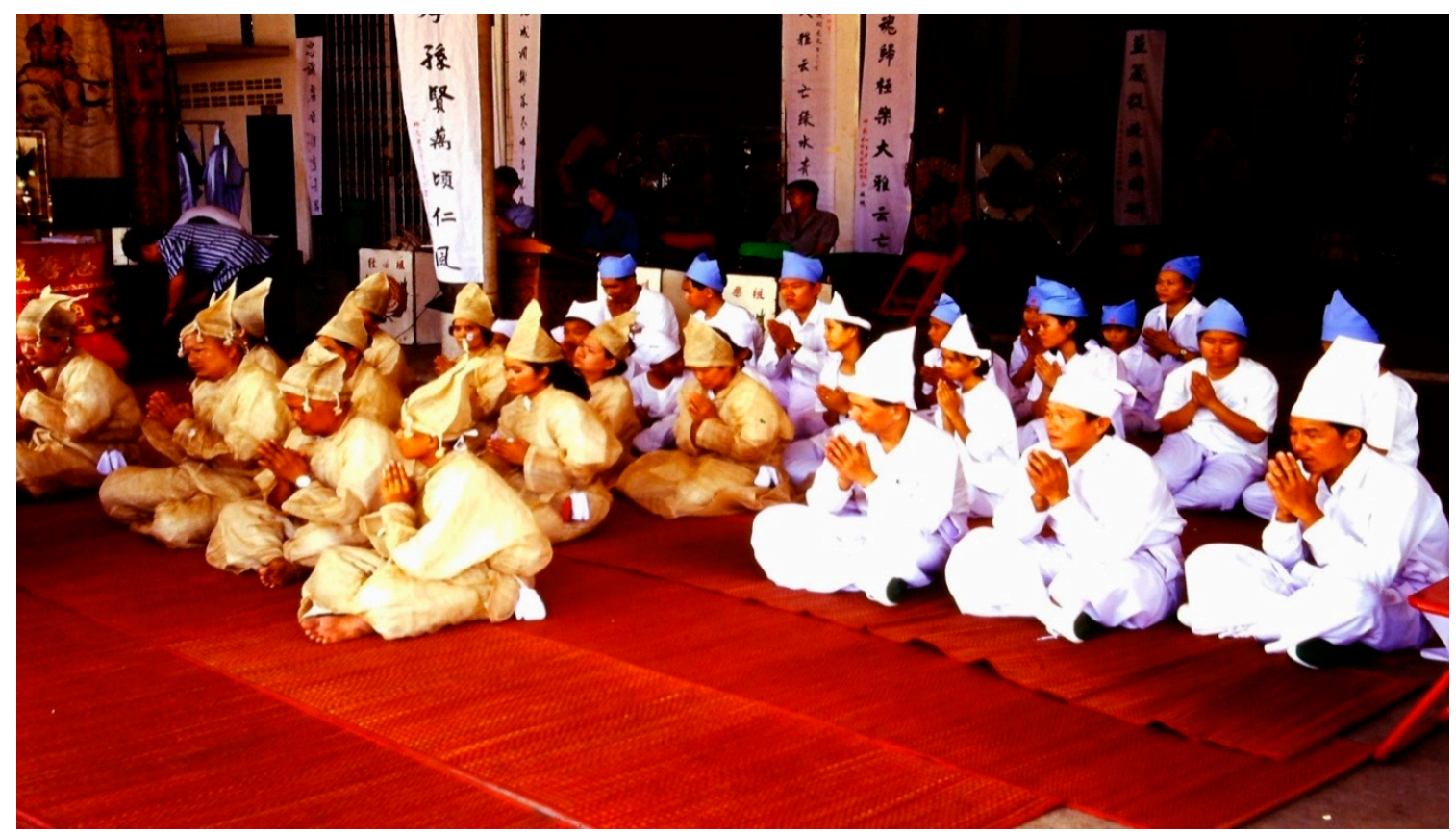

Figure 1. Mourners and the audience in the background. Déjiāo, Khon Kaen, Thailand, 1993 (C) B. Formoso). 
The performative process of rebirth, which is an important component of funerals, is based on the moral obligation of gratitude and reciprocity that binds children to their parents. ${ }^{6}$ Through this process, the former pay off to the latter the debt of life induced by their birth and the care received throughout childhood. The imperative of a rebirth in the underworld, that nevertheless retains the deceased within the kinship group as one of its powerful and benevolent members, passes through an intermediate ontological concern: "to keep corpse and spirit together during the initial stages of death" (Watson 1988b, p. 8). Preserving the integrity of the person who just passed away and maintaining his/her social integration within the kinship group are then inextricably linked. They express the will of the kin group, and beyond the society, to continue to operate strict control over individual existence in the afterlife.

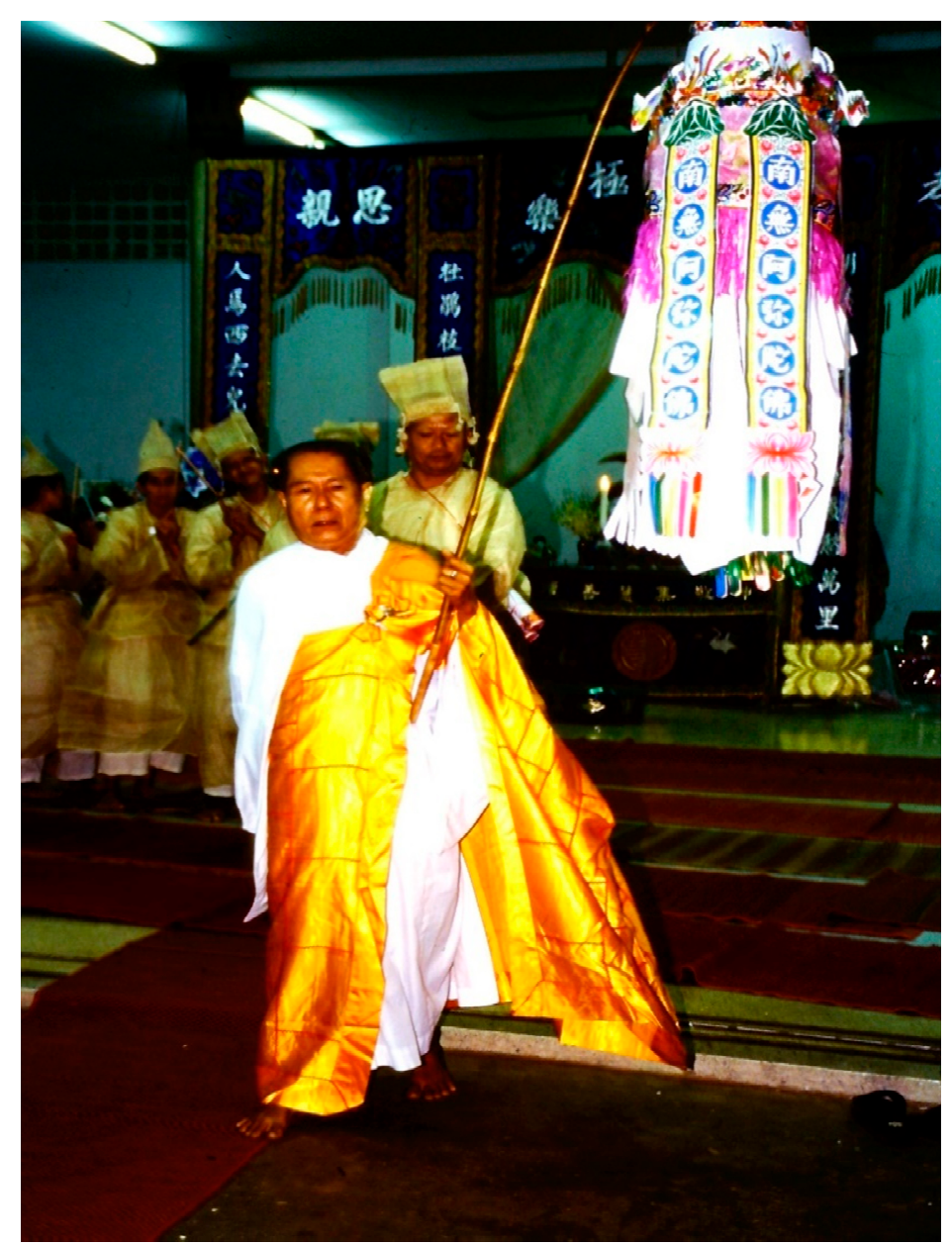

Figure 2. A Daoist priest guiding the soul of the deceased during a gōng dé ritual, Thailand, 1994 (C) B. Formoso).

To absorb the pollution emanating from the decaying flesh and from the "killing airs" (shāqi 殺氣), that is, the vital biological forces released by the corpse, are part of the marks of gratitude and solidarity towards the dead that his/her family must display during the funeral. James Watson pointed out that "in order for the spirit of the deceased to be properly settled, these vital forces must be absorbed back

6 The way my informants expressed the terms of this reciprocity is very well rendered by Emily Ahern when she writes: "The living are expected to care for the dead in payment of the debt they owe them. Beyond this, in the act of meeting this obligation, the living hope to inspire a further reciprocal response from the ancestors, to obtain through them the good life as they perceive it: wealth, rich harvests, and offspring who will ensure undying memory and sustenance in the afterlife" (Ahern 1973, p. 91). 
into the flesh of living people" (Watson 1988a, p. 114). Women are thought to be better equipped than men to carry out this task, because of their symbolic identification with the yin principle, and with flesh at the level of the body components. This is why it falls to women of the patriline to bathe the corpse with water that the chief mourner has purchased from the deity of a well, and to proceed to the final change of clothing. For their part, the daughters-in-law also pass a feather duster over the coffin after it has been sealed, as a symbol of their dedication to domestic tasks and of their respect for the deceased. The pollution absorbed by the family to a greater degree than other people attending the ritual is partially neutralized at the end of the burial, when the whole of the audience is sprinkled with purifying water that the priest has prepared. For that purpose, the water is mixed with pomegranate leaves and the ashes of protective diagrams.

To close these brief remarks on funerals of normal dead, it is necessary to consider the way in which their future destiny is imagined. Although Chinese funeral rites incorporate elements of Buddhist cosmology (representations of hell and of the Western Paradise 西天, for instance), and soteriology (emphasis in scriptures and liturgy on good deeds as a privileged means to improve the karma), my informants saw reincarnation as a distant and hypothetical issue. Expressing a common point of view, the chief priest of one of the Déjiāo associations I studied once explained to me that reincarnation is possible, but that the ancestors to whom their descendants ensure a good life in the underworld have no desire to return to earth. This way of thinking must be related to the fact that redemption is not a primary objective of Chinese mortuary rites. Myron Cohen makes the point when she writes:

Rather than focusing on the salvation of the dead, Chinese funeral and post-funeral ritual was concerned first with aiding the deceased's passage through the underworld's ten courts and then with providing him or her in that very same underworld with as comfortable a material life as possible. (Cohen 1988, p. 187)

\section{The Ritual Refining of Unfortunate Dead}

The $x i \bar{u} g \bar{u} g u$ festival that we are going to discuss now is performed without significant variation by the different Chaozhou chains of temples of Thailand, including Déjiāo. It differs from funerals on several important points. First, it is a rite of second burial. As such, it does not deal with fresh corpses, but with old bones that need to be exhumed beforehand. The place where these remains can be found is known for those who have been stored for years in the cemetery of the association, but it must be subject to survey for some of them, hastily buried in fallow areas and who have been forgotten. This leads us to a second difference. The officiants who play a driving role in the $x i \bar{u} g \bar{u} g \dot{u}$ are mediums that the people of Chaozhou call tángkī 童乩 (Chinese: tóngjì). Unlike priests who implement a prescribed script and choreography, the mediums are the instruments of the gods' will and agency. As such, they set the calendar of the various ritual sequences, locate the wandering souls, lead them to the temple, and identify their gender and status. The mediums, who are mostly men, are believed to be in "fate affinity" (yuán fèn 缘份) with the deities they embody. They deliver instructions in writing messages by means of a forked branch from a willow tree. The technique, called fújī, combines two different features, that of the "scholars" or wénji 文乩 and that of the "warriors" or wŭji 武乩. Whereas the former consists mainly in the gentle writing of moral poetry, the latter usually assumes a rugged disposition, since the mediums fight malevolent spirits and enter into trances. Wüji is the dominant mode of action in the context of $x i \bar{u} g \bar{u} g \dot{u}$, because the wandering spirits often resist the call of the deities.

Mediums always act in pairs, because they express the yin/yang complementarity during the process of spirit-writing. The $j \overline{\text { -}}$-wielder who holds one arm of the fork with his right hand, but stands on the left side while facing the altar, is considered as the yang and "heaven's hand" (tiānshŏu 天手); his fellow who holds the other arm of the fork with his left hand, and stands on the right side while facing the altar, is thought to be yin. As Jan Jakob Maria de Groot pointed out (De Groot 1910, p. 1297), this assistant merely behaves neutrally, abstaining from disturbing the movements of the "heaven's 
hand." When, after prayers and burning incense, the two "jī-hands" (jīshŏu 乩手), as they are commonly called, begin to shake, and the stick follows their movements by tracing characters, it means that the gods have come down.

The various supports the Déjiāo mediums use, as well as the ways in which their messages are written down perfectly express the lack of liturgical homogeneity within this NRM. In some congregations, the tray where the gods' messages are delivered is a square symbolizing earth, and which is put on the floor with the mediums sitting down to write oracles, whereas elsewhere, it is a table and the $j \bar{j}$-wielders remain standing. In the latter case, the table may be square, circular, or octagonal. The material used to write varies accordingly. Though in most cases, characters are traced back on the sand, on incense ashes, or a combination of both; sometimes it is through a thin layer of tea or holy water poured down on the platters that the gods express oracles. These messages, or shìù 示喻 (instructions of imperial edicts), are read by assistants, the bàoyù 喻 who stand around the platter and transmit them in a loud voice to clerks, the jīy ù 喻, sitting nearby. The scribes and readers are educated men, who are able to transcript divine language into legible human writing.

As mentioned above, one of the first concerns of the family at the funerals was to hold together

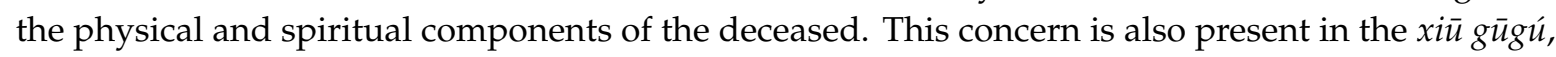
but to a lesser extent. Although bones' gatherers strive to bring whole skeletons back to the temple, it does not matter if parts are missing. It is thought that the worshippers have tried their best to calm the restless ghost, by bringing together all the physical marks of its previous life. It also happens that the spots indicated by the mediums contain no bones. Gods being infallible, it is simply assumed that some spirit used to haunt the place, but that its bones have been either scattered or buried elsewhere. In such a case, the prospectors lay on the ground a roll of white paper containing mock money and having clothes, furniture and other household goods printed on it. The roll is burnt as an offering. This is done to "dress" the soul, who otherwise would be bare without a skeleton, and to provide it with the luxury goods printed on the sheet. The lighting of the burning paper is also said to guide the wandering soul to the medium.

By definition, the orphaned souls have no descendants to take care of their transfer to the underworld. Although the Déjiāo dédé shè 德德社, the Déjiāo "god's society" and its followers, intends to act as an adoptive family for these restless ghosts, social and emotional distances are pronounced towards them, because of their anonymity and potential dangerousness. Very significantly, the process of their ritual transfer to the underworld under the aegis of the association's deities is doubled, in the case of the $x i \bar{u} g \bar{u} g u$, by an additional control device, which is supposed to integrate them definitively into the lap of a well-ordered "society of the orphaned [dead]" (güshè 孤社). The device takes shape in the layout of the collective grave and in the disposal of the bones inside. In all the Déjiāo ritual performances that I observed in Thailand in the 1990s, and in Chaozhou between 2003 and 2005, the group grave, which can contain thousands of jars or bags of bones in some cases, is conceived as a house, with a central hall named huì yiting 会依亭 (meeting hall), two lateral bedrooms, and two bathrooms, one for each gender. While the skeletons identified as male are arranged in rows on the left half of the grave, those seen as female are put on the right side. The God's society, acting through the mediums, appoints among the dead a king, a queen, and a court of six ministers whose function is to rule the whole cohort. In Thailand, a Buddhist monk is also appointed among the orphan dead and gold leaves cover the king's skull. The jars or bags containing the remains of these leaders occupy the front row of the grave. The ability of the king to enact decrees and laws is symbolized by an inkpot, put into his jar/bag, together with the usual items accompanying the dead (gold papers, furniture, clothes, and valuables printed on a sheet of paper, and a Buddhist sutra to open the way to the underworld). It is noteworthy that the mediums do not ascribe a patronymic or a lineage identity to the ghosts and to their "rulers." Unlike the normal dead who are constitutive elements of descent lines and whose pedigree must be clearly identified accordingly, anomalous dead are "adopted" as an alien and anonymous stock. Their non-personification is crucial to mark a clear-cut distinction between private ancestor worship and a communal cult of unclaimed dead. 
The distance maintained with these dead also relates to their evil power. While the deceased parents are credited with benevolence, it is the opposite for the wandering souls. They are perceived as frustrated and revengeful. This is why the $x i \bar{u} g \bar{u} g \bar{u}$ intends to neutralize the danger they embody by transferring them properly to the underworld. Therefore, the first ritual sequence of the $x i \bar{u} g \bar{u} g \hat{u}$ consists of the Déjiāo mediums producing an abundance of protective diagrams drawn on cotton squares of the three auspicious colors yellow-red-green, and that the members of the association attending the festival will have to wear day and night.

As mentioned above, the pollution emanating from the decaying corpse of the dead is a source of danger at the funeral, but what about the handling of bones? According to Watson (1982, pp. 158-59), death pollution presents two aspects for the Cantonese (including the Chaozhou people): the first aspect is active, associated with the release of the spirit; the second aspect is passive, relating to the decay of the flesh that corresponds to the yin aspect. Whereas the transformation of the corpse from flesh to bone makes the passive aspect become residual, the pollution associated with the dead spirit has lingering effects. By properly sending the dead spirit to the underworld, the $x i \bar{u} g \bar{u} g u$ neutralizes the active aspect, while the ritual step consisting of washing the bones completes the process of physical purification. Bone gatherers in Chaozhou and Thailand also believe that the proper handling of bones by men and women, whatever the status and origin of the dead, allows those who do it to take on the positive and powerful yang property associated with bones.

In order to purify the bones of all traces of pollution, worshippers must purify themselves. While constraints and taboos separate the mourners from the audience at funerals, all the participants are subject to the same protective and purifying provisions during the $x i \bar{u} g \bar{u} g \dot{u}$. From the first day of the festival to its end, the participants will have to observe a strict discipline. They must wear white clothes day and night, and eat only vegetarian food. To show that they fully respect this precept, they take all their meals at the temple's canteen. They also have to refrain from sexual intercourse. Here again, those most concerned (such as the cult community's leaders) sleep in the temple guest house to avoid suspicion of misbehavior. Lastly, they ought to use holy water regularly for drinking and washing. This washing can be seen below in Figure 3.

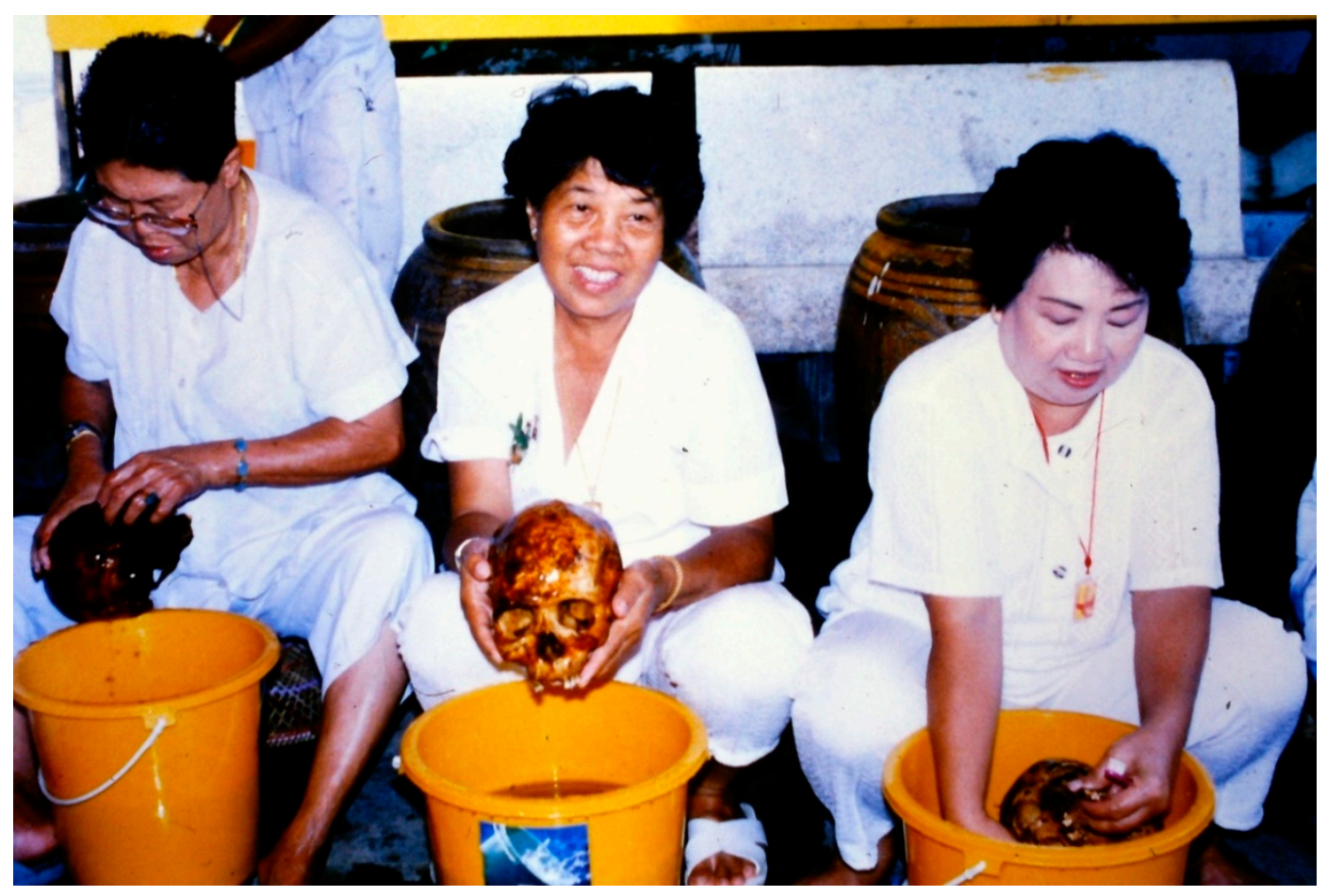

Figure 3. Déjiāo bones' gatherers washing skulls during a xī̄ gūgú, Roeit, Thailand, 1994 (C) B. Formoso). 


\section{The Ritual Sequences of the Festival}

After reviewing the main differences between the funeral and the $x i \bar{u} g \bar{u} g \dot{u}$ festival, let us come now to a sketchy description of the latter. First, it needs to be noted that the festival is usually celebrated between April and June. This period of the year is favored because it coincides with the end of the dry season and consequently there is no heavy rains to disrupt the work of digging out the bones. The festival lasts seven, 36, 49, 64, or 90 days, according to astrological cycles and the amount of Thai skeletons that remain to be collected, a good part of the festival being devoted to their collection.

The festival's first day starts with a séance of wŭjī in which the Déjiāo mediums move to a corner of the temple courtyard and point with their forked divining pencil the spots at which to set up five bamboo sticks, their tops hooded with protective diagrams. These sticks are arranged in the four cardinal directions, with the fifth stick in the center. According to some informants, they represent the five elements (fire, wood, water, metal, and earth) and, according to others, they symbolize the Generals of the Five Directions, commanders of the devil-destroying army of the God of Heaven, whose function is to protect the festival against malevolent spirits. Although referring to different symbols, the two interpretations meet in that they express the will of the cult community to make the courtyard of the temple a secure microcosm. The placing in the courtyard of altars to Buddhist and Daoist deities representing different stages of the universe (Earth God, Nine Star Gods, the Buddhist Ruler of the Underworld ... ) confirms this will.

While the temple's courtyard may be considered the spatial focus of the festival, other places are significant as well. One is the cemetery of a Déjiāo association where most orphaned dead await their refining. This cemetery is the setting of the next ritual stage, which takes place on an auspicious date. This ritual is aimed at opening the "Mother Mountain" (mŭshān 母山), as Chaozhou people metaphorically call the $x i \bar{u} g \bar{u} g \dot{u}$ group grave and, by extension, the cemetery of the association. On this occasion, a silent procession goes to the cemetery. Vegetarian food offerings are made, both to the Generals of the Five Directions who protect the place, and to its guardian spirit. Then, the mediums run to the cemetery, waving their swords to chase out devils, and they indicate with their forked branches the spots where the prospectors will find skeletons. Bamboo sticks with red pennants are used to mark the spots, and the mediums continue, while teams of diggers exhume the corpses. In the case of the "Mother Mountain" cemetery, these operations offer no surprises, since the dead are buried in individual cement vaults, which are easy to locate. Each skeleton is assembled on a white sheet of paper. If the remains are those of a man, the prospectors try to appease the soul further by putting a lighted cigarette in the jaws. After a short while the bones are put into individual containers and the gender of the dead is written on a label tied to it. It should be stressed that carrying them, far from being avoided for fear of death pollution, is a praiseworthy act. These containers are termed "treasure bag" (băobāo 宝包), since carrying them brings inestimable merits. To prevent quarrelling over the privilege of transporting them, a human chain is usually organized in the courtyard, in order to convey them to store rooms. There are two such rooms, one for each gender. Lastly, a wénjī séance is performed in the evening. Through the mediums, the "honorable masters" who patronize the association express their feelings, give new commands and indicate the exact number of wandering souls that have been attracted to the ceremonial ground.

Bone collection activities are repeated according to this pattern almost every day, for a variable period of time. Small provincial associations in Thailand usually do not have enough bodies stored in their cemetery. Therefore, they must explore Thai Buddhist inhumation places devoted to the unfortunate dead to find more corpses. Located in rural villages, these places are selected because of their potential, as ascertained by earlier surveys. Another factor is that the Buddhist local clergy villagers must give their permission for the corpses to be taken away.

The finding of mummified corpses during the collection campaign run by one or several Déjiāo associations working together is a very auspicious event, especially when they are embryos or bodies of young children. In the latter case, the mummies are called "golden boys" (jinntóng 金童) or "jade girls" (yùniáng 玉娘), according to their gender. The epithets "gold" and "jade" are usually applied in 
China to young associates of deities. In the present case, Déjiāo followers want to express both the decay-resistance of these dead and the high value conferred on them. According to a common belief in the Chinese world (Faure 1991; Gildow 2005), our Déjiāo informants were persuaded that these dead have resisted the process of decay, because of an exceptional imbalance in favor of their yang aspect. Consequently, the mummies are believed to have turned into very powerful spirits. A shrine dedicated to them is erected in a corner of the temple's courtyard.

The gathering campaign always ends where it started: in the "Mother Mountain" graveyard. This idea of a perfect cycle works on a temporal level as well, since the opening of the association's cemetery must take place in the early morning, and the closing should happen in the late afternoon. It is also worth noting that the auspicious number nine, which embodies the supreme ultimate in Daoism ${ }^{7}$, is used to arrange the timing and duration of the bone gathering. Thus, the number of days of bone gathering should end with this number (nine, 19, or 29 for instance), while the same figure is used to choose the starting times of the rituals (9:09 a.m., for example, in the case of the "opening of the Mother Mountain").

The next phase of the ritual cycle takes place a few days later and consists, as for the funeral, of purchasing water to the God of a spring indicated by the patron saints of the association. Old men draw the water and pour it into containers. In order to reinforce the purifying power of this water, magic diagrams drawn by the "honorable masters" are burnt and mixed with it, here again in analogy with funeral rites performed by Déjiāo. The cleansing of the skeletons takes place the next day. The bones are taken out of the bags, passed along a human chain and meticulously washed with lustral water. Then, the skulls are arranged in rows in the temple's courtyard and left to dry in the sun for a few days, while the other bones are packed and stored. A strict division by gender is observed, with the skulls of men and women being displayed in separate sections of the courtyard, and the bags of bones being put away in different rooms.

The following day, a gōng dé ritual is performed. The role of surrogate family for the orphaned souls is then taken over by the worship community, with the president of the charitable association acting, in the liturgy, as a substitute for the eldest son. Under the patronage of an Immortal, the participants obtain from the King of Hell, Yánluó Wáng 閻籮王, permission to break the gates of the underworld to allow communication between the worlds and to enable all the dead to take advantage of the good deeds realized by the living through prayers, prostrations and offerings. Finally, the Immortal and the surrogate family make the dead souls symbolically cross the seven oceans of Chinese cosmology to reach the Western Paradise (xītiān 西天). However, informants in practice regard this paradise as only opened to the most virtuous, for most people must first expiate their faults in one of the realms of the underworld (dìyù 地獄).

The next day, in the afternoon, disposal rites take place. The comparison of their performance in Chaozhou and Thailand confirms the remark of Watson (1988, p. 205), that the guideline of this category of rites is more flexible and subject to political manipulation than funeral rites. In Chaozhou, once dried the skeletons are put into jars allegorically called huájīn 华金 (blossoming gold), to express an auspicious transfer of the dead to the underworld and a desirable prospective rebirth. To this end, the disposal of remains in the jars is believed to reproduce the fetal position. In Thailand, due to the injunctions of the monarchy for the festival to respect Thai death rituals, Déjiāo and the other local shàntáng, have inserted a new sequence before the burial of the remains in the "Mother Mountain" grave, namely cremation. For that purpose they do not use jars anymore but cotton bags. Firstly, the bones are transported by means of these containers to the place of cremation. In this place, the bones are extracted from the bags and are piled up according to their gender into two large chimney pyres (seen in Figure 4), called by means of Buddhist metaphors, "treasure pagoda" (băotă 宝塔) for males and

7 Cheu Hock-Tong summarizes the significance of this number: "The nine orifices as well as the nine celestial breaths and the nine palaces of the brain are embodied in a single body (microcosmos) just as the nine original heavens are represented in a single universe (macrocosmos)" (Cheu 1982, p. 13). 
“lotus pond" (liánhuā chí 莲花池) for females. These chimneys may be seen as collective jars because the bones are laid inside so that they form a single megacorpse, with the bones of the feet and legs at the bottom, those of the trunk and arms occupying the intermediate position, and the skulls arranged to form a pyramid at the top. The symbolism of a well-ordered social body is then preserved in a vertical rather than horizontal way. Two other features characterize the layout: an umbrella, emblem of the Siamese king, overhangs the skulls of the rulers at the top of the pyramid; and if remains of a monk have been identified, they are draped with a monastic gown and set at the apex to represent the overwhelming spiritual power of the Buddha.

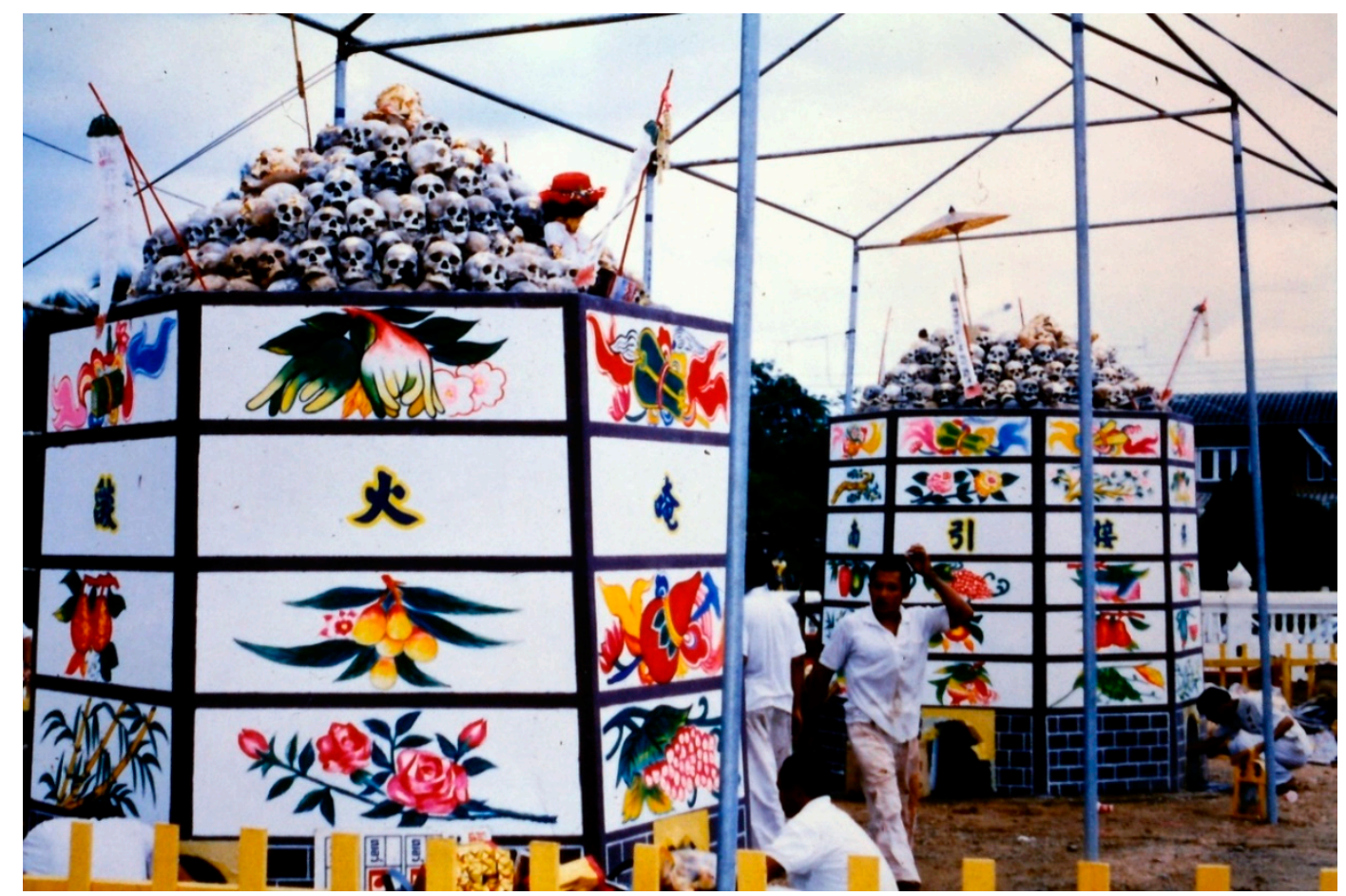

Figure 4. The two chimney stakes containing skeletons, Roeit, Thailand, 1994 (C) B. Formoso).

Usually, on the night preceding the cremation, mediums of the association go to areas of the city where accidents, suicides and homicides have been reported. There, they determine the number of wandering souls haunting them. Then, the same number of paper offerings are burnt, to make the spirits into the cohort of dead to be sent to the underworld.

After the cremation, the ashes are left to cool for three days. Finally, devotees put the ashes into white bags whose name, băoná 宝拿 (treasure hold), perfectly expresses the prospect for wealth related to the manipulation of the dead bones. A procession headed by statues of the Déjiāo "honorable masters" carry these bags to the cemetery. There, they are stored in the association's collective grave. Following the symbolism in use in Chaozhou, the grave is conceived as a house that comprises a vault for each gender. For their part, the bags that the mediums identified as containing the rulers' ashes and of the mummies occupy the front stage. This final arrangement of the remains respects the Chaozhou tradition, without infringing on local customs: the Thai burying part of the ashes and putting the rest into an urn stored within the Buddhist temple's compound.

The burial of the remains concludes what the Chinese call the "white affairs" (báishì 白事); namely the rituals dealing with death. From the next stage onwards, the ritual concluding the festival belongs to the "red affairs" (hóngshi 红事), which deal with life, and whose main purpose is to thank the gods and to seek prosperity for the living. The first "red affairs" ceremony is called shōuchá 收茶 (to receive tea) and takes place the morning after the burial. On this occasion, the mediums lead a joyful procession around the town. The procession stops in front of shops where food has been 
set out on tables. The foods are dry tea, which is the minimal element, cakes, fruits and vegetarian dishes. The mediums put prophylactic red marks on all the items with the tip of their forked branch. In return, each shopkeeper offers a portion of dry tea to the guardian divinities of the city through the representatives of the Déjiāo association. The rest is conserved by the shopkeeper's household, and believed to bring health and good luck.

The next afternoon starts a rite in every aspect similar to the Universal Salvation Festival. Briefly summarized, the purpose of this ritual is to make the gods charged with the control of souls in the underworld to come into the temple's courtyard and, with them, all the dead they watch over, in order to receive food offerings. On this occasion, the devotees take part in a Buddhist religious office, in the course of which monks pray for the salvation of the souls. One of them, embodying the Bodhisattva Mù Lián 目蓮 (Maudgalyāyana), reminds the audience of filial piety. According to legend, Mù Lián, one of the two main disciples of the Buddha, used magical powers to rescue his mother who had been reborn as a hungry ghost in the deepest regions of the netherworld. At the end of the office, the monk representing Mù Lián throws lucky charms to the audience in the form of uncooked rice, small boxes of tiger's balm, candies, cakes, and coins. Afterwards, the participants arrange great quantities of vegetarian food and offer them to the hungry ghosts on the temple's courtyard. Offerings are also made to the ancestors.

Over the next three days, Buddhist monks are invited to the temple to recite sutras, bringing peace to the living. Chinese theatre is also performed to entertain the gods. At the beginning of these performances, the actors present to the gods puppets which represent the sons of an Immortal woman and are believed to give male offspring to people who handle them. Finally, the ritual cycle of the $x i \bar{u} g \bar{u} g u$ is closed by an offering of food at the collective grave. This ceremony institutes the grave as an auspicious and protected dwelling place for the dead.

\section{Conclusions}

Déjiāo funeral and $x i \bar{u}$ gūgú share many goals. In both cases, the living act on the dead to guarantee their own prosperity, health and longevity. To do this, they build a ritual relationship of lasting gift-type exchange with the dead, which makes their respective well-being closely dependent. In both cases, too, the rites aim to maintain the dead souls in a social order, which allows the regulation and control of their activities, in order to avoid any dangerous spillover. The family-matrix of the society as a whole-is in charge of such a control, operating through ancestor commemoration rites, in the case of "natural" death. Regarding the orphaned dead, the Déjiāo Gods' Society provides this supervision, which is also a form of re-enculturation, by acting as a surrogate family; but because of the dangerousness of these ghosts, the $x i \bar{u} g \bar{u} g \dot{u}$ strengthens the device through an arrangement of the collective grave, which creates on its scale, a kingdom of the dead.

Funerals and $x i \bar{u} g \bar{u} g \dot{u}$ also manage the pollution caused by death and perform a purification of the corpse, but not in the same way. Whereas the mourners must manage the active and passive aspects of pollution at the funeral, $x i \bar{u} g \bar{u} g \dot{u}$ is mainly concerned with the active aspect through the release of the spirit. Moreover, bone handling during the Chaozhou festival allows those who do it to take on the positive yang property associated with bones. A striking feature in both contexts is the unchallenging domination of the women in all operations involving direct contact with the dead. The cleaning of the bones, and their transport to the Déjiāo temple and to the cemetery, are mainly carried out by women. The same is true of the funerals of individuals, at which women cleanse the corpse, dress the dead and dust the coffin. If at the funeral women take on the yin fertility of the deceased, embodied in the flesh, during the $x i \bar{u} g \bar{u} g \hat{u}$, they conversely absorb the yang, a complementary aspect which contributes to long life.

The performance of $x i \bar{u}$ gūgú by local associations of Déjiāo in Thailand is of specific significance, given the redemptive vocation of this Chinese NRM. By bringing wandering souls back into the cycle of rebirth and converting evil spirits into benevolent ones, the festival offers a perfect opportunity for Déjiāo, to publicly display its concern for universal salvation in a national context, where the 
ethnic Chinese are often accused of being greedy materialists. By overtly relating the prosperity of humankind to the salvation of the anomalous dead that both Chinese and Thai fear, the $x i \bar{u} g \bar{u} g u$ is instrumental for Déjiāo to set up a universal community of living and dead, incorporating "benevolent ancestors from all origins and generations" as its bone gatherers in Thailand commonly name the unfortunate dead they refine. In such a way, the overseas participants to the festival aggregate to their own descent line an adjunct that reflects the polyethnic and cosmopolitan society within which they live. They also symbolically reverse their actual condition: subjected to a policy of assimilation, they conversely subject part of the native dead to their own cosmological order.

Funding: This research was funded in 2003 by the Chiang Ching-Kuo Foundation for International Scholarly Exchange.

Conflicts of Interest: The author declares no conflict of interest.

\section{References}

Ahern, Emily. 1973. The Cult of the Dead in a Chinese Village. Stanford: Stanford University Press.

Cheu, Hock-Tong. 1982. An Analysis of the Nine Emperor Gods Spirit-Medium Cult in Malaysia. Ph.D. thesis, Cornell University, Ithaca, NY, USA.

Cohen, Myron L. 1988. Souls and Salvation: Conflicting Themes in Chinese Popular Religion. In Death Ritual in Late Imperial and Modern China. Edited by James L. Watson and Evelyn Rawski. Berkeley: University of California Press, pp. 180-202.

De Groot, Jan J. M. 1910. The Religious System of China. Vol. 6: War against Spectres. The Priestwood of Animism. Book 2. Leyden: E.J. Brill.

Duara, Prasenjit. 2001. The Discourse of Civilization and Pan-Asianism. Journal of World History 12: 99-130. [CrossRef]

Eliott, Alan J. A. 1955. Chinese Spirit-Medium Cults in Singapore. London: London School of Economics and Political Science.

Faure, Bernard. 1991. The Rethoric of Immediacy: A Cultural Critique of Chan/Zen Buddhism. Princeton: Princeton University Press.

Formoso, Bernard. 1996. Chinese Temples and Philanthropic Associations in Thailand. Journal of Southeast Asian Studies 27: 245-60. [CrossRef]

Formoso, Bernard. 2010. De Jiao, A Religious Movement in Contemporary China and Overseas: Purple Qi from the East. Singapore: National University of Singapore Press.

Gildow, Douglas. 2005. Flesh Bodies, Stiff Corpses, and Gathered Gold: Mummy Worship, Corpse Processing, and Mortuary Ritual in Contemporary Taiwan. Journal of Chinese Religion 33: 2-45. [CrossRef]

Katz, Paul R. 2007. Orthopraxy and Heteropraxy beyond the State: Standardizing Ritual in Chinese Society. Modern China 33: 72-90. [CrossRef]

Naquin, Susan. 2000. Peking. Temples and City Life, 1400-1900. Berkeley: University of California Press.

Palmer, David A. 2011. Chinese Redemptive Societies and Salvationist Religion: Historical Phenomenon or Sociological Category. Journal of Chinese Theatre, Ritual and Folklore 172: 21-72.

Rowe, William T. 1984. Hankow: Commerce and Society in a Chinese City, 1796-1889. Stanford: Stanford University Press.

Schipper, Kristopher. 1993. The Taoist Body. Berkeley: University of California Press. First published 1982.

Shahar, Meir. 1998. Crazy Ji: Chinese Religion and Popular Literature. Cambridge: Harvard University Asia Center. Tong, Chee-Kiong. 2004. Chinese Death Ritual in Singapore. London: Routledge/Curzon.

Watson, James L. 1982. Of Flesh and Bones: The Management of Death Pollution in Cantonese Society. In Death and the Regeneration of Life. Edited by Maurice Bloch and Jonathan Parry. Cambridge: Cambridge University Press, pp. 155-86.

Watson, James L. 1988a. Funeral Specialists in Cantonese Society: Pollution, Performance, and Social Hierarchy. In Death Ritual in Late Imperial and Modern China. Edited by James L. Watson and Evelyn Rawski. Berkeley: University of California Press, pp. 109-34. 
Watson, James L. 1988b. The Structure of Chinese Funerary Rites: Elementary Forms, Ritual Sequence, and the Primacy of Performance. In Death Ritual in Late Imperial and Modern China. Edited by James L. Watson and Evelyn Rawski. Berkeley: University of California Press, pp. 3-19.

Watson, James L. 1993. Rites or Beliefs? The Construction of a Unified Culture in Late Imperial China. In China's Quest for National Identity. Edited by Samuel S. Kim and Lowell Dittner. Ithaca: Cornell University Press, pp. 80-92.

Watson, Rubie S. 1988. Remembering the Dead: Graves and Politics in Southern China. In Death Ritual in Late Imperial and Modern China. Edited by James L. Watson and Evelyn Rawski. Berkeley: University of California Press, pp. 203-227.

Weller, Robert. 1985. Bandits, Beggars, and Ghosts: The Failure of State Control over Religious Interpretation in Taiwan. American Ethnologist 12: 46-61. [CrossRef]

Willmott, W. E. 1970. The Political Structure of the Chinese Community in Cambodia. New York: Humanities Press.

(C) 2020 by the author. Licensee MDPI, Basel, Switzerland. This article is an open access article distributed under the terms and conditions of the Creative Commons Attribution (CC BY) license (http://creativecommons.org/licenses/by/4.0/). 